\title{
Screening Quinoxaline-Type Donor Polymers for Roll-to-Roll Processing Compatible Organic Photovoltaics
}

\section{SUPPORTING INFORMATION}

Audrey Laventure, ${ }^{\mathrm{a}}$ Cayley R. Harding, ${ }^{\mathrm{a}}$ Edward Cieplechowicz, ${ }^{\mathrm{a}} \mathrm{Zhe} \mathrm{Li},{ }^{\mathrm{b}} \mathrm{Ju}$ Wang, ${ }^{\mathrm{b}}$ Yingping Zou, ${ }^{\text {,** }}$ and Gregory C. Welch ${ }^{\mathrm{a}, *}$

a Department of Chemistry, University of Calgary, 2500 University Drive N.W., Calgary, Alberta, Canada T2N 1N4

${ }^{\mathrm{b}}$ College of Chemistry and Chemical Engineering, Central South University, Changsha 410083, China

* Corresponding Authors

Email: yingpingzou@csu.edu.cn

Email: gregory.welch@ucalgary.ca; Phone number: 1-403-210-7603

\section{Table of Contents}

Materials and Methods 


\section{Materials and Methods}

Materials: QX1, QX3, QX4 polymers ${ }^{1-3}$ and $\mathrm{tPDI}_{2} \mathrm{~N}-\mathrm{EH}^{4}$ were synthesized as previously reported. The synthesis of QX2 is reported at the end of the Supporting Information.

Cyclic Voltammetry (CV): Electrochemical measurements were performed using a Model 1200B Series Handheld Potentiostat by $\mathrm{CH}$ Instruments Inc. The cyclic voltammetry experiments were performed in anhydrous solution with $\sim 0.1 \mathrm{M}$ tetrabutylammonium hexafluorophosphate (TBAPF6) as the supporting electrolyte using dichloromethane solvent with Ag wire pseudo reference, Pt wire counter electrode, and glassy carbon electrode working electrode. All electrochemical solutions were purged with dry $\mathrm{N}_{2}$ for 5 minutes to deoxygenate the system. Solution CV measurements were carried out with a small molecule concentration of $\sim 0.5 \mathrm{mg} / \mathrm{mL}$ in dichloromethane. The ionization potentials (IP) and electron affinities (EA) were estimated by correlating the onsets $\left(\mathrm{EoxFc} / \mathrm{Fc}^{+}, \mathrm{Ered} F c / \mathrm{Fc}^{+}\right)$to the normal hydrogen electrode (NHE), assuming the IP of $\mathrm{Fc} / \mathrm{Fc}^{+}$to be $4.80 \mathrm{eV} .^{5}$

UV-Visible Spectroscopy (UV-Vis): All absorption measurements were recorded using Agilent Technologies Cary $60 \mathrm{UV}-\mathrm{V}$ is spectrometer at room temperature. Neat films were prepared by spin-coating from a $1 \% \mathrm{wt} / \mathrm{v}$ solution onto clean Corning glass micro slides. Prior to use, glass slides were cleaned with soap and water, acetone and isopropanol, and followed by UV/ozone treatment using a Novascan UV/ozone cleaning system.

Photoluminescence (PL): All emission measurements were recorded using an Agilent Technologies Cary Eclipse fluorescence spectrophotometer at room temperature.

Polarized Optical and Fluorescence Microscopy: POM (cross-polarization) and FM images were taken using a BX53 Olympus Optical Microscope equipped with a BX3-URA unit and a Xcite 120 LEDmini light source. A designated filter selectively allows green light to be transmitted to the sample, while red light sourced at the sample is selectively transmitted to the digital camera.

Atomic Force Microscopy (AFM): AFM measurements were performed by using a TT2-AFM (AFM Workshop) in tapping mode and WSxM software with an 0.01-0.025 Ohm/cm Sb (n) doped $\mathrm{Si}$ probe with a reflective back side aluminum coating. Samples for AFM measurement were the same ones that were used to collect the respective the device parameters.

Power Conversion Efficiency (PCE) and External Quantum Efficiency (EQE): The current density-voltage $(\mathrm{J}-\mathrm{V})$ curves were measured by a Keithley 2420 source measure unit. The photocurrent was measured under AM 1.5 illumination at $100 \mathrm{~mW} / \mathrm{cm}^{2}$ under a Solar Simulator (Newport 92251A-1000). The standard silicon solar cell (Newport 91150V) was used to calibrate light intensity. EQE was measured in a QEX7 Solar Cell Spectral Response/QE/IPCE Measurement System (PV Measurement, Model QEX7, USA) with an optical lens to focus the light into an area about $0.04 \mathrm{~cm}^{2}$, smaller than the dot cell. The silicon photodiode was used to calibrate the EQE measurement system in the wavelength range from 300 to $1100 \mathrm{~nm}$. 

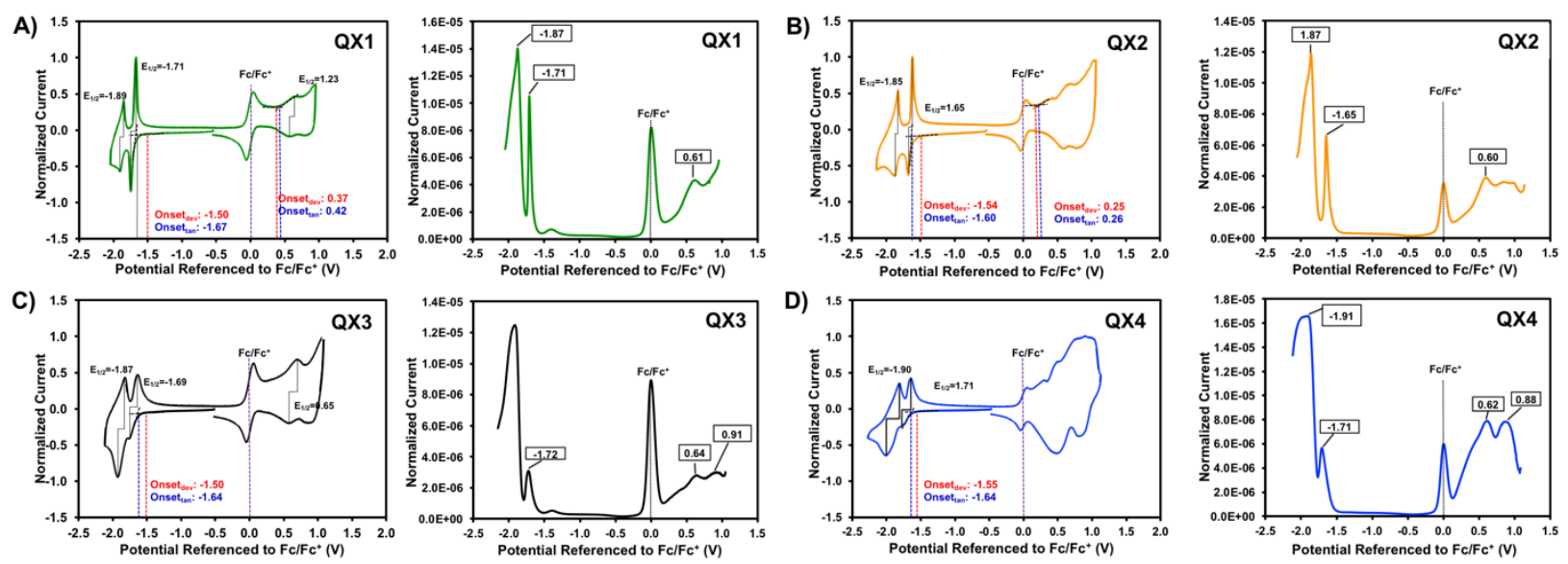

Figure S1. Cyclic and differential pulse voltammograms of A) QX1, B) QX2, C) QX3, and D) QX4 used to determine the energy levels of the polymers.

A)

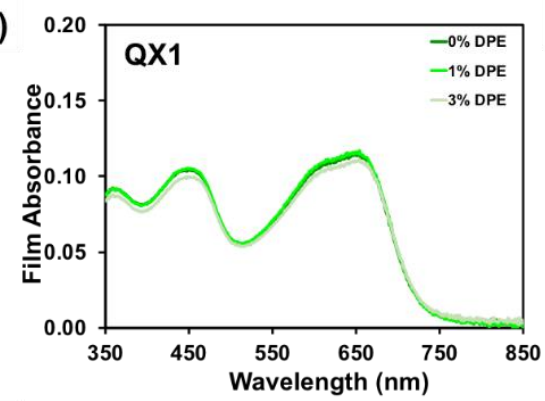

C)

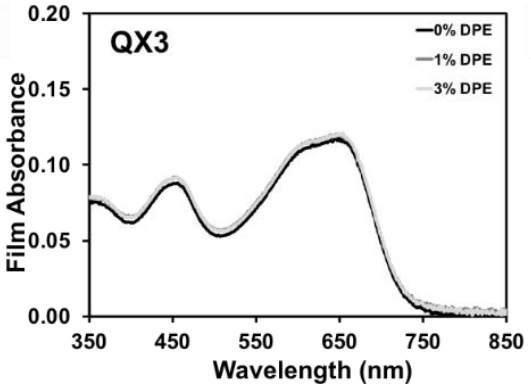

B)

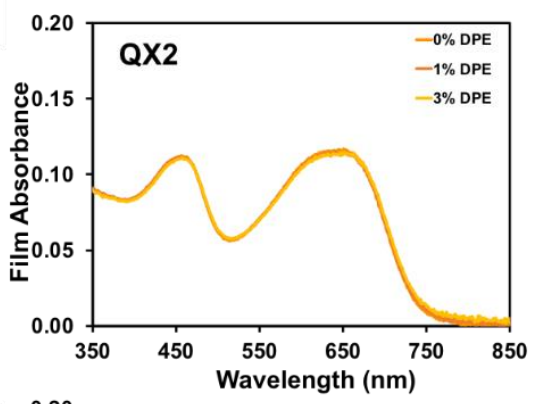

D)

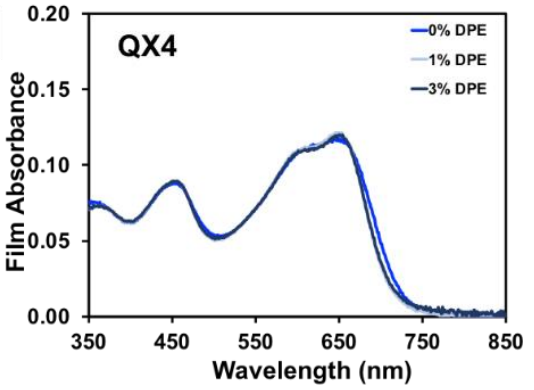

Figure S2. UV-visible spectra of A) QX1, B) QX2, C) QX3, and D) QX4 films spin-coated from $o$-xylenes containing 0,1 or $3 \%(\mathrm{v} / \mathrm{v}) \mathrm{DPE}$. 


\section{OPV devices}

Devices were fabricated using ITO-coated glass substrates cleaned by sequentially ultra-sonicating with detergent and de-ionized water, acetone, and isopropanol followed by exposure to UV/ozone for $30 \mathrm{~min}$. $\mathrm{ZnO}$ was subsequently deposited as a sol-gel precursor solution in air following the method of Sun et al. ${ }^{6}$ The room temperature solution was filtered and spin-coated at a speed of $4000 \mathrm{rpm}$ and then annealed at $200{ }^{\circ} \mathrm{C}$ in air for $15 \mathrm{~min}$.

Active layer solutions of QX1-4 and $\mathrm{tPDI}_{2} \mathrm{~N}-\mathrm{EH}$ were prepared in air with a total concentration of $10 \mathrm{mg} / \mathrm{mL}$ in $o$-xylenes with or without a $1-3 \%$ (v/v) diphenylether (DPE) additive. Solutions were stirred overnight at room temperature. Active layer materials were combined in a 1:1 donor/acceptor weight ratio. For spin-coated devices, the active layer solution was coated at room temperature at a speed of $1000 \mathrm{rpm}$ for $60 \mathrm{~s}$. For slot-die coated devices, the active layer solution was coated using a compact sheet coater from FOM Technologies equipped with a $13 \mathrm{~mm}$ wide slot-die head using a solution dispense rate of $80 \mu \mathrm{L} / \mathrm{min}$ and a substrate motion speed of 30 $\mathrm{cm} / \mathrm{min}$.

The substrates with the cast active layers were kept in an $\mathrm{N}_{2}$ atmosphere glovebox overnight before evaporating $\mathrm{MoO}_{3}$ and $\mathrm{Ag}$. The $10 \mathrm{~nm}$ of $\mathrm{MoO}_{3}$ followed by $100 \mathrm{~nm}$ of $\mathrm{Ag}$ were thermally deposited under vacuum ( $1 \times 10^{-5}$ Torr). The active areas of the devices were $0.09 \mathrm{~cm}^{2}$.

\section{$\underline{\text { Device optimization }}$}

Table S1. OPV data of QX1-QX4: $\mathrm{tPDI}_{2} \mathrm{~N}-\mathrm{EH}$ blends (1:1) spin-coated from $o$-xylenes containing 0,1 or $3 \%(\mathrm{v} / \mathrm{v})$ DPE. Best PCE results are highlighted in bold. Averages are in italics.

\begin{tabular}{|c|c|c|c|c|}
\hline Active layer & $V_{\text {oc }}(\mathrm{V})$ & $\mathrm{J}_{\mathrm{sc}}\left(\mathrm{mA} / \mathrm{cm}^{2}\right)$ & FF (\%) & PCE (\%) \\
\hline \multicolumn{5}{|l|}{ QX1 } \\
\hline \multirow[t]{5}{*}{$0 \%(\mathrm{v} / \mathrm{v}) \mathrm{DPE}$} & 1.05 & 9.66 & 49.3 & 4.99 \\
\hline & 1.03 & 9.63 & 48.4 & 4.82 \\
\hline & 1.05 & 9.49 & 50.7 & 5.05 \\
\hline & 1.05 & 9.35 & 50.4 & 4.97 \\
\hline & 1.05 & 9.53 & 49.7 & 4.96 \\
\hline \multirow{5}{*}{$3 \%(\mathrm{v} / \mathrm{v}) \mathrm{DPE}$} & 1.03 & 7.18 & 60.8 & 4.48 \\
\hline & 1.05 & 8.38 & 59.4 & 5.25 \\
\hline & 1.03 & 9.40 & 59.3 & 5.74 \\
\hline & 1.02 & 9.46 & 55.7 & 5.36 \\
\hline & 1.03 & 8.61 & 58.8 & 5.21 \\
\hline \multicolumn{5}{|l|}{ QX2 } \\
\hline \multirow[t]{5}{*}{$0 \%(\mathrm{v} / \mathrm{v}) \mathrm{DPE}$} & 1.05 & 9.36 & 43.7 & 4.29 \\
\hline & 1.05 & 9.43 & 43.9 & 4.35 \\
\hline & 1.05 & 8.47 & 43.5 & 3.86 \\
\hline & 1.02 & 8.90 & 39.8 & 3.62 \\
\hline & 1.04 & 9.04 & 42.7 & 4.03 \\
\hline \multirow[t]{5}{*}{$3 \%(\mathrm{v} / \mathrm{v}) \mathrm{DPE}$} & 1.03 & 8.34 & 54.3 & 4.67 \\
\hline & 1.03 & 8.28 & 54.1 & 4.61 \\
\hline & 1.03 & 8.20 & 55.1 & 4.66 \\
\hline & 1.03 & 8.48 & 54.3 & 4.77 \\
\hline & 1.03 & 8.33 & 54.5 & 4.68 \\
\hline
\end{tabular}




\begin{tabular}{|c|c|c|c|c|}
\hline \multicolumn{5}{|l|}{ QX3 } \\
\hline \multirow[t]{5}{*}{$0 \%(\mathrm{v} / \mathrm{v}) \mathrm{DPE}$} & 1.05 & 7.58 & 45.0 & 3.59 \\
\hline & 1.08 & 8.09 & 48.2 & 4.20 \\
\hline & 1.06 & 7.65 & 47.9 & 3.89 \\
\hline & 1.08 & 7.82 & 48.8 & 4.12 \\
\hline & 1.07 & 7.79 & 47.5 & 3.95 \\
\hline \multirow[t]{5}{*}{$3 \%(\mathrm{v} / \mathrm{v}) \mathrm{DPE}$} & 1.05 & 6.53 & 53.5 & 3.67 \\
\hline & 1.05 & 6.64 & 54.0 & 3.77 \\
\hline & 1.06 & 7.58 & 55.4 & 4.47 \\
\hline & 1.06 & 7.49 & 52.2 & 4.12 \\
\hline & 1.05 & 6.96 & 53.5 & 3.93 \\
\hline \multicolumn{5}{|l|}{ QX4 } \\
\hline \multirow[t]{5}{*}{$0 \%(\mathrm{v} / \mathrm{v}) \mathrm{DPE}$} & 1.06 & 9.69 & 46.8 & 4.83 \\
\hline & 1.07 & 10.26 & 46.2 & 5.09 \\
\hline & 1.06 & 9.61 & 48.1 & 4.90 \\
\hline & 1.06 & 10.35 & 46.1 & 5.07 \\
\hline & 1.06 & 9.98 & 46.8 & 4.97 \\
\hline \multirow[t]{5}{*}{$3 \%(\mathrm{v} / \mathrm{v}) \mathrm{DPE}$} & 1.04 & 8.85 & 56.2 & 5.17 \\
\hline & 1.05 & 8.38 & 59.4 & 5.25 \\
\hline & 1.03 & 9.40 & 59.3 & 5.74 \\
\hline & 1.02 & 9.46 & 55.7 & 5.36 \\
\hline & 1.04 & 9.02 & 57.6 & 5.38 \\
\hline
\end{tabular}

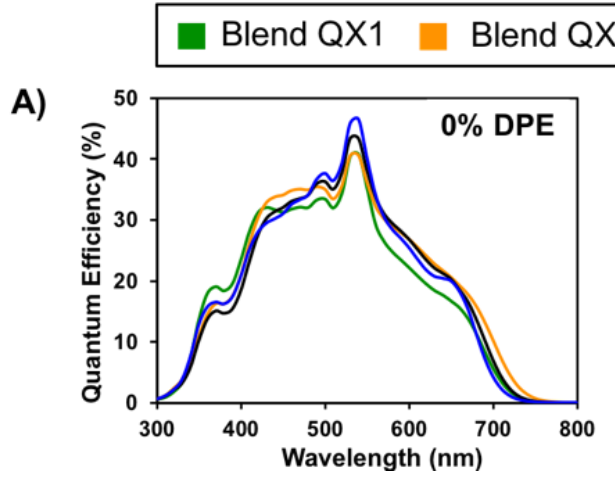

\section{Blend QX3 Blend QX4}

B)

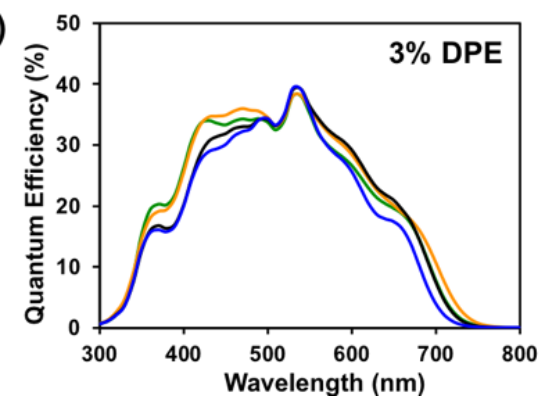

Figure S3. External quantum efficiency profile of the QX1-4:tPDI $2 \mathrm{~N}-\mathrm{EH}$ (1:1 blend) devices spincoated from $o$-xylenes on top of glass/ITO/ZnO containing 0 or $3 \%(\mathrm{v} / \mathrm{v}) \mathrm{DPE}$.

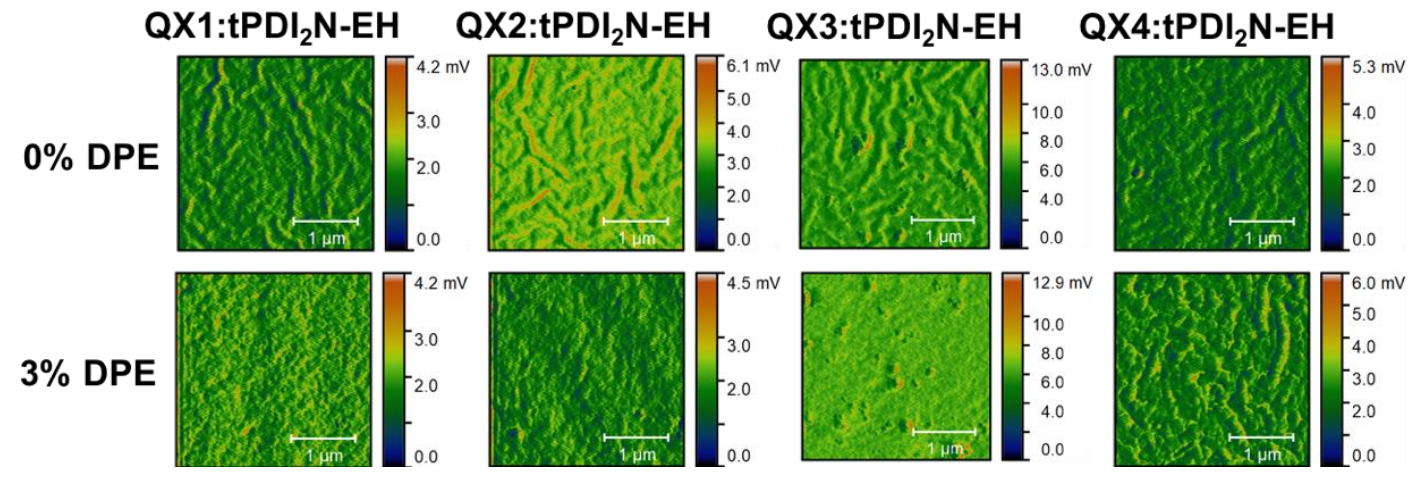

Figure S4. AFM phase images of the QX1-4: $\mathrm{tPDI}_{2} \mathrm{~N}-\mathrm{EH}$ (1:1 blend) spin-coated from $o$-xylenes containing 0 or $3 \%(\mathrm{v} / \mathrm{v}) \mathrm{DPE}$ as a solvent additive. 
A)

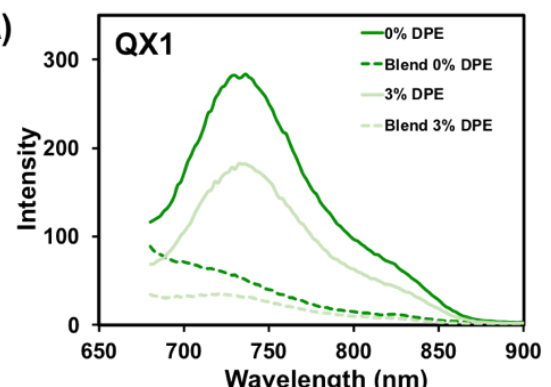

C)

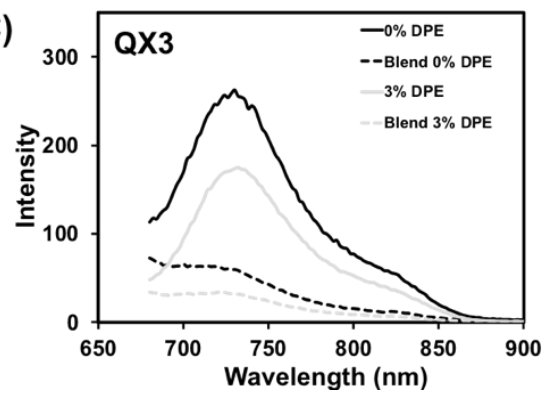

B)

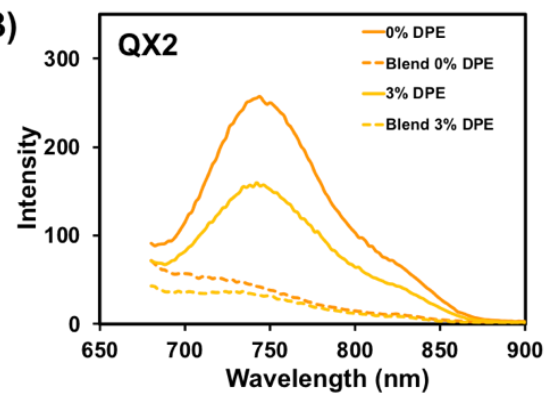

D)

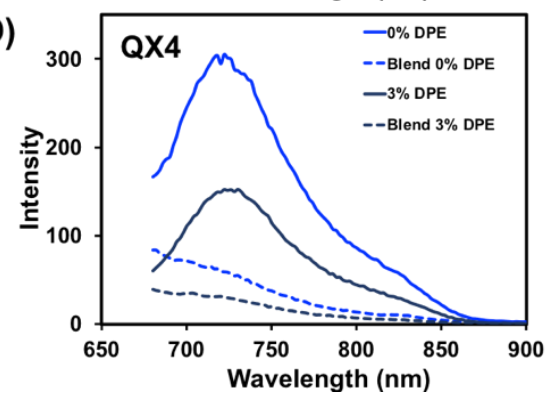

Figure S5. Photoluminescence spectra of A) QX1, B) QX2, C) QX3 and D) QX4 and their respective blends with $\mathrm{PPDI}_{2} \mathrm{~N}-\mathrm{EH}(1: 1)$ blends spin-coated from $o$-xylenes with 0,1 or $3 \%(\mathrm{v} / \mathrm{v})$ DPE additive.

Table S2. OPV data of QX1: $\mathrm{PPDI}_{2} \mathrm{~N}-\mathrm{EH}$ blends (1:1) spin-coated from $o$-methylanisole containing 0 or $3 \%(\mathrm{v} / \mathrm{v})$ DPE. Best PCE results are highlighted in bold. Averages are in italics.

\begin{tabular}{|c|c|c|c|c|}
\hline Active layer & $V_{\text {oc }}(\mathrm{V})$ & $\mathrm{J}_{\mathrm{sc}}\left(\mathrm{mA} / \mathrm{cm}^{2}\right)$ & FF (\%) & PCE (\%) \\
\hline \multirow[t]{8}{*}{$0 \%(\mathrm{v} / \mathrm{v}) \mathrm{DPE}$} & 1.04 & 10.60 & 49.1 & 5.40 \\
\hline & 1.04 & 10.74 & 49.2 & 5.51 \\
\hline & 1.04 & 10.63 & 49.7 & 5.52 \\
\hline & 1.05 & 11.41 & 48.7 & 5.85 \\
\hline & 1.05 & 11.61 & 48.6 & 5.91 \\
\hline & 1.05 & 10.97 & 48.4 & 5.55 \\
\hline & 1.05 & 11.05 & 47.9 & 5.57 \\
\hline & 1.05 & 11.00 & 48.8 & 5.61 \\
\hline \multirow{9}{*}{$3 \%(\mathrm{v} / \mathrm{v}) \mathrm{DPE}$} & 1.03 & 9.63 & 56.9 & 5.63 \\
\hline & 1.03 & 10.06 & 58.4 & 6.07 \\
\hline & 1.03 & 9.50 & 56.1 & 5.47 \\
\hline & 1.04 & 9.16 & 59.0 & 5.61 \\
\hline & 1.04 & 9.39 & 58.9 & 5.74 \\
\hline & 1.04 & 9.34 & 59.2 & 5.74 \\
\hline & 1.03 & 9.56 & 58.7 & 5.81 \\
\hline & 1.03 & 9.53 & 58.6 & 5.77 \\
\hline & 1.03 & 9.52 & 58.2 & 5.73 \\
\hline
\end{tabular}


Table S3. OPV data of QX3: $\mathrm{tPDI}_{2} \mathrm{~N}-\mathrm{EH}$ blends $(1: 1)$ slot-die coated from $o$-xylenes containing $3 \%(\mathrm{v} / \mathrm{v})$ DPE. Best PCE results are highlighted in bold. Averages are in italics.

\begin{tabular}{|c|c|c|c|c|}
\hline \multirow{6}{*}{\begin{tabular}{|l|} 
Additive \\
$3 \%(\mathrm{v} / \mathrm{v}) \mathrm{DPE}$
\end{tabular}} & $V_{\text {oc }}(\mathrm{V})$ & $\mathrm{J}_{\mathrm{sc}}\left(\mathrm{mA} / \mathrm{cm}^{2}\right)$ & FF (\%) & PCE (\%) \\
\hline & 1.01 & 6.57 & 50.4 & 3.35 \\
\hline & 1.05 & 6.68 & 56.7 & 3.98 \\
\hline & 1.06 & 6.93 & 56.1 & 4.11 \\
\hline & 1.05 & 6.27 & 57.0 & 3.76 \\
\hline & 1.04 & 6.61 & 55.0 & 3.80 \\
\hline
\end{tabular}

Table S4. Exploration of processing conditions for OPV devices of QX1:tPDI $2 \mathrm{~N}-\mathrm{EH}$ blends (1:1) spin-coated from $o$-xylenes and $o$-methylanisole. Average of two devices.

\begin{tabular}{|c|c|c|c|c|}
\hline $\begin{array}{l}\text { Processing } \\
\text { conditions }\end{array}$ & $\mathbf{V}_{\text {oc }}(\mathrm{V})$ & $\mathrm{J}_{\mathrm{sc}}\left(\mathbf{m A} / \mathbf{c m}^{2}\right)$ & FF (\%) & PCE (\%) \\
\hline \multicolumn{5}{|l|}{$o$-xylenes } \\
\hline $20 \mathrm{mg} / \mathrm{mL}$ & 1.02 & 9.80 & 32.7 & 3.26 \\
\hline $\begin{array}{l}\text { Thermal annealing } \\
\text { (TA, } 180^{\circ} \mathrm{C}, 10 \\
\text { min) }\end{array}$ & 1.01 & 9.56 & 54.9 & 5.30 \\
\hline $3 \% \mathrm{DPE}+\mathrm{TA}$ & 0.98 & 8.04 & 50.5 & 3.98 \\
\hline \multicolumn{5}{|l|}{$o$-methylanisole } \\
\hline $20 \mathrm{mg} / \mathrm{mL}$ & 1.00 & 8.77 & 31.6 & 2.77 \\
\hline $\begin{array}{l}\text { Thermal annealing } \\
\left(\mathrm{TA}, 180^{\circ} \mathrm{C}, 10\right. \\
\text { min) }\end{array}$ & 0.97 & 10.28 & 45.3 & 4.54 \\
\hline $3 \% \mathrm{DPE}+\mathrm{TA}$ & 0.99 & 8.79 & 60.8 & 5.27 \\
\hline $\begin{array}{l}\text { Solvent vapor } \\
\text { annealing (SVA, } 10 \\
\text { min with THF) }\end{array}$ & 1.00 & 8.93 & 47.2 & 4.22 \\
\hline $\begin{array}{l}\text { SVA with o- } \\
\text { methylanisole }\end{array}$ & 1.03 & 9.33 & 52.3 & 5.04 \\
\hline
\end{tabular}




\section{QX2 synthesis details}

n-Butyllithium (n-BuLi), Lithium diisopropylamide (LDA), Tetrabutylammonium fluoride (TBAF), trimethylchlorosilane $(\mathrm{Me} 3 \mathrm{SiCl})$, tetrabromothiophene, 3,6-Dibromo-4,5difluorobenzene-1,2-diamineo-difluorobenzene, Zinc powder, iron powder were purchased from Energy Chemical. Tetrakis(triphenylphosphine)palladium(0) $\quad\left(\mathrm{Pd}\left(\mathrm{PPh}_{3}\right)_{4}\right) \quad$ and bis(triphenylphosphine)palladium(II)dichloride $\left(\mathrm{PdCl}_{2}\left(\mathrm{PPh}_{3}\right)_{2}\right)$ were obtained from J\&K Chemical, THF was distilled over sodium and benzophenone, and toluene was dried over $\mathrm{P}_{2} \mathrm{O}_{5}$ and freshly distilled prior to use. 3-Bromothiophene,2,6-bis(trimethyltin)-4,8-bis(5-(2ethylhexyl)thiophene-2-yl)benzo[1,2-b:4,5-b']dithiophene (M2), and other solvents were purchased from Aldrich and TCI Chemical Co, respectively.

Tetrabromothiophene, 3,4-Dibromothiophene 1

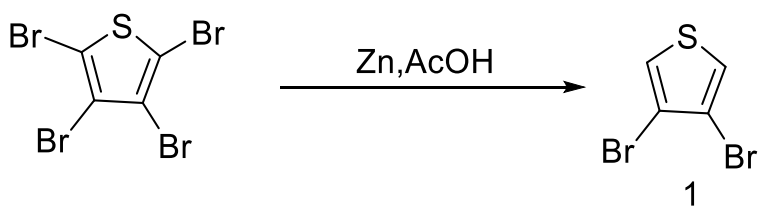

In a $500 \mathrm{~mL}$ flask with $160 \mathrm{~mL}$ glacial acetic acid-water $(1: 2, \mathrm{v} / \mathrm{v})$, tetrabromothiophene $(100 \mathrm{~g}$, $250 \mathrm{mmol})$ and zinc powder $(53.1 \mathrm{~g}, 810 \mathrm{mmol})$ were added. The mixture was stirred for one hour at room temperature, and then stirred under reflux for another three hours. The mixture was cooled to room temperature and filtered to remove the excess zinc powder; the filtrate was extracted with dichloromethane. The combined organic portions were washed several times with water and then dried over magnesium sulfate. The crude product, which remained after the solvent had evaporated, was distilled under reduced pressure and a colorless oil was obtained. $(51.7 \mathrm{~g}, 85 \%$ yield). ${ }^{1} \mathrm{H}$ NMR (400 MHz, $\left.\mathrm{CDCl}_{3}\right) \delta 7.31$ (s, 2H).

\section{3,4-Dibromo-2-(2-ethylhexyl) thiophene 2}
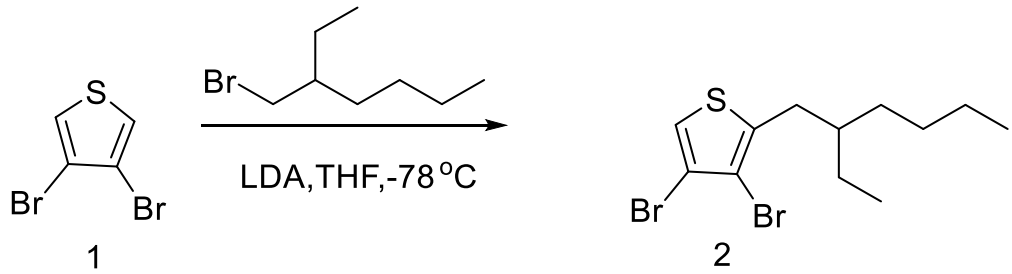

A 2.0 M lithium diisopropyl amide (LDA) in THF (64.6 mL, $155 \mathrm{mmol})$ was added to a solution of 3,4-dibromothiophene $(25.8 \mathrm{~g}, 106.8 \mathrm{mmol})$ in THF $(200 \mathrm{~mL})$ at $-78{ }^{\circ} \mathrm{C}$ over $20 \mathrm{~min}$. The mixture was stirred at $-78^{\circ} \mathrm{C}$ for $30 \mathrm{~min}$, and then a 2- ethylhexyl bromide $(31.2 \mathrm{~g}, 161.5 \mathrm{mmol})$ was added to the mixture. After the addition, the reaction mixture was heated at $70{ }^{\circ} \mathrm{C}$ for $12 \mathrm{~h}$. The reaction mixture was poured into the water, extracted with dichloromethane, and dried with anhydrous $\mathrm{MgSO} 4$. The solvent was removed via rotary evaporation, and the residue was purified by vacuum distillation to give a colorless liquid. Yield: $19.84 \mathrm{~g}(52.5 \%) .{ }^{1} \mathrm{H} \mathrm{NMR}(400 \mathrm{MHz}$, $\left.\mathrm{CDCl}_{3}\right) \delta 7.20(\mathrm{~s}, 1 \mathrm{H}), 2.76(\mathrm{~d}, \mathrm{~J}=7.1 \mathrm{~Hz}, 2 \mathrm{H}), 1.67-1.65(\mathrm{~m}, 1 \mathrm{H}), 1.36-1.29(\mathrm{~m}, 8 \mathrm{H}), 091-0.87$ $(\mathrm{m}, 6 \mathrm{H})$. 


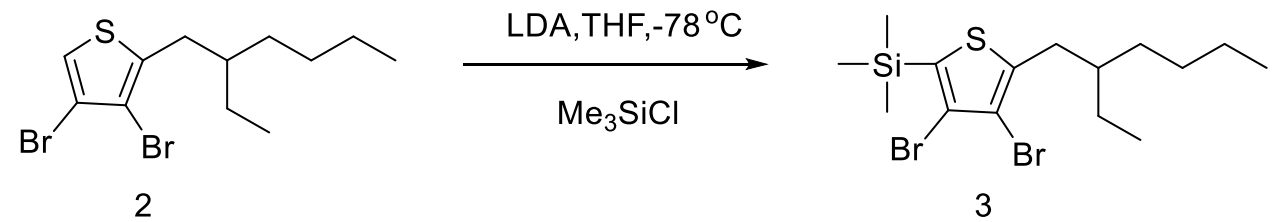

To a solution of compound $2(19.6 \mathrm{~g}, 55,2 \mathrm{mmol})$ in THF $(140 \mathrm{~mL})$, a $2.0 \mathrm{M}$ solution of LDA (41.6 $\mathrm{mL}, 83.2 \mathrm{mmol}$ ) was added, and the mixture was stirred at $-78{ }^{\circ} \mathrm{C}$ and for $1 \mathrm{~h}$ and chlorotrimetylsilane $(11.4 \mathrm{~mL}, 87.7 \mathrm{~mol})$ was added slowly. The solution was warmed to room temperature and stirred at room temperature for $5 \mathrm{~h}$. The reaction mixture was then poured into water and extracted with dichloromethane. After drying over anhydrous $\mathrm{MgSO}_{4}$, and the solvent evaporated. The product was purified by column chromatography on silica gel with n-hexane as eluent to afford compound 3. Yield: $21.2 \mathrm{~g}(90.1 \%)$. Fab-MS: $\mathrm{m} / \mathrm{z}=426 .{ }^{1} \mathrm{H}$ NMR (400 MHz, $\left.\mathrm{CDCl}_{3}\right) \delta 2.75(\mathrm{~d}, \mathrm{~J}=6.8 \mathrm{~Hz}, 2 \mathrm{H}), 1.69-1.64(\mathrm{~m}, 5.8 \mathrm{~Hz}, 1 \mathrm{H}), 1.31-1.29(\mathrm{~m}, 8 \mathrm{H}), 0.91-0.88(\mathrm{~m}$, $6 \mathrm{H}), 0.39-0.37(\mathrm{~m}, 9 \mathrm{H})$.

(5-(2-Ethylhexyl)-3,4-difluorothiophen-2-yl) trimethylsilane 4

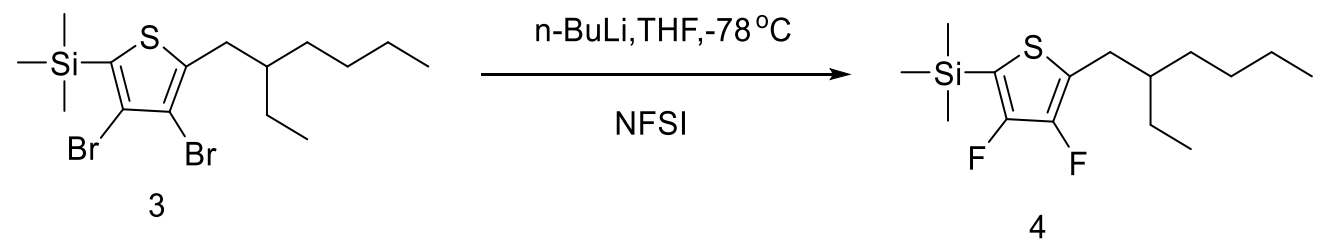

A $2.5 \mathrm{M}$ of $\mathrm{n}-\mathrm{BuLi}$ in THF $(13.7 \mathrm{~mL}, 34.3 \mathrm{mmol})$ was added to a solution of compound $3(9.54 \mathrm{~g}$, $22.37 \mathrm{mmol})$ in THF $(120 \mathrm{~mL})$ at $-78{ }^{\circ} \mathrm{C}$ over $20 \mathrm{~min}$. The mixture was stirred at $-78{ }^{\circ} \mathrm{C}$ for 30 min. $\left(\mathrm{PhSO}_{2}\right)_{2} \mathrm{NF}(10.82 \mathrm{~g}, 34.31 \mathrm{mmol})$ was added in one portion, and the mixture was stirred at $-78{ }^{\circ} \mathrm{C}$ for $30 \mathrm{~min}$. Further lithiation and fluorination were repeated three times with n-BuLi (7.2 $\mathrm{mL}, 17.9 \mathrm{mmol}$ ), $\left(\mathrm{PhSO}_{2}\right)_{2} \mathrm{NF}$ (NFSI) $(5.64 \mathrm{~g}, 17.9 \mathrm{mmol})$, n-BuLi $(3.9 \mathrm{~mL}, 8.95 \mathrm{mmol}$ ), $\left(\mathrm{PhSO}_{2}\right)_{2} \mathrm{NF}(2.82 \mathrm{~g}, 8.95 \mathrm{mmol}), \mathrm{n}-\mathrm{BuLi}(3.9 \mathrm{~mL}, 8.95 \mathrm{mmol})$ and $\left(\mathrm{PhSO}_{2}\right)_{2} \mathrm{NF}(2.82 \mathrm{~g}, 8.95$ mmol). The solution was warmed to room temperature and stirred at room temperature for $5 \mathrm{~h}$. The reaction mixture was poured into $1 \mathrm{M} \mathrm{HCl}(200 \mathrm{~mL})$. The mixture was extracted with $\mathrm{CHCl}_{3}$, and dried with anhydrous $\mathrm{MgSO}_{4}$. The solvent was removed via rotary evaporation, the product was purified by column chromatography on silica gel with $\mathrm{n}$-hexane as eluent to afford a colorless liquid 4. Yield: $4.5 \mathrm{~g}(66 \%) .{ }^{1} \mathrm{H} \mathrm{NMR}\left(400 \mathrm{MHz}, \mathrm{CDCl}_{3}\right) \delta 2.63(\mathrm{~d}, \mathrm{~J}=6.7 \mathrm{~Hz}, 2 \mathrm{H}), 1.59-1.55$ (m, 1H), 1.33-1.29 (m, 8H), $0.91-0.87(\mathrm{~m}, 6 \mathrm{H}), 0.32-0.31(\mathrm{~m}, 9 \mathrm{H})$.

\section{2-(2-Ethylhexyl)-3,4-difluorothiophene 5}

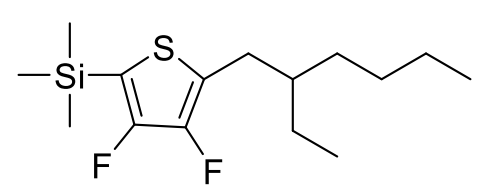

4

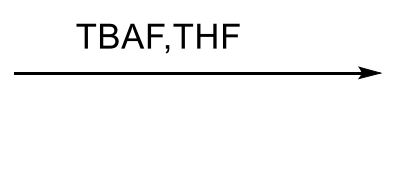

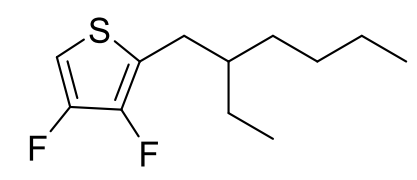

5

A $1.0 \mathrm{M}$ of tetrabutylammonium fluoride (TBAF) in THF ( $36 \mathrm{~mL}, 36 \mathrm{mmol}$ ) was added to a solution of compound $4(10 \mathrm{~g}, 32.84 \mathrm{mmol})$ in THF $(160 \mathrm{~mL})$, and the resulting solution was 
stirred at room temperature for $3 \mathrm{~h}$. The mixture was extracted with $\mathrm{CHCl}_{3}$ and water, and dried over anhydrous $\mathrm{MgSO}_{4}$. The solvent was evaporated and the residue was purified by column chromatography on silica gel with n-hexane as eluent to afford compound 5. Yield: $5 \mathrm{~g}(65.6 \%)$. ${ }^{1} \mathrm{H}$ NMR $\left(400 \mathrm{MHz}, \mathrm{CDCl}_{3}\right) \delta 6.49(\mathrm{dd}, \mathrm{J}=3.7,1.2 \mathrm{~Hz}, 1 \mathrm{H}), 2.64(\mathrm{~d}, \mathrm{~J}=6.8 \mathrm{~Hz}, 2 \mathrm{H}), 1.58-1.55$ $(\mathrm{m}, 1 \mathrm{H}), 1.34-1.29(\mathrm{~m}, 8 \mathrm{H}), 0.91-0.88(\mathrm{~m}, 6 \mathrm{H})$.

\section{1,2-Bis(5-(2-ethylhexyl)-3,4-difluorothiophen-2-yl)ethane-1,2-dione 6}

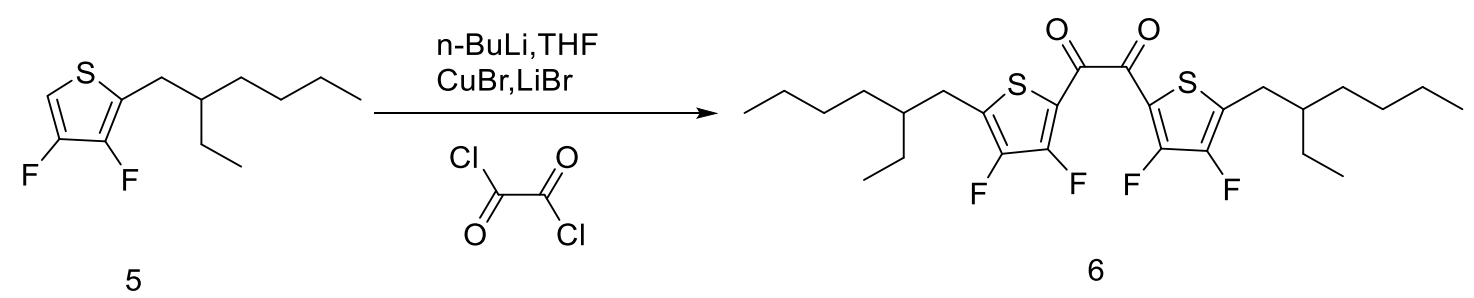

To the compound $5(3.15 \mathrm{~g}, 13.6 \mathrm{mmol})$ in anhydrous THF $(20 \mathrm{~mL})$, the $\mathrm{n}$-BuLi $(5.4 \mathrm{~mL}, 13.57$ mmol) was added at $78{ }^{\circ} \mathrm{C}$ under argon and the reaction mixture was stirred for $2 \mathrm{~h}$. Then the mixture was added slowly to lithium bromide $(2.52 \mathrm{~g}, 28.9 \mathrm{mmol})$ and cuprous bromide $(1.95 \mathrm{~g}$, $13.57 \mathrm{mmol})$ dispersed in $30 \mathrm{~mL}$ THF at $0^{\circ} \mathrm{C}$. After $1 \mathrm{~h}$ of stirring, the oxalyl chloride $(0.78 \mathrm{~g}, 6.15$ mmol) was added and the reaction mixture was stirred for $30 \mathrm{~min}$ at $0{ }^{\circ} \mathrm{C}$ and for another $2 \mathrm{~h}$ at room temperature. Then the mixture was poured into water, extracted with dichloromethane, and the organic extraction was washed thoroughly with water and aqueous sodium bicarbonate. The organic phase was dried over magnesium sulfate and evaporated to afford the crude product. The crude product was purified by column chromatography on a silica gel using hexane as eluent. The product 6 was obtained as a light yellow viscous liquid $\left(0.69 \mathrm{~g}, 21.6 \%\right.$ yield). ${ }^{1} \mathrm{H} \mathrm{NMR}(400 \mathrm{MHz}$, $\left.\mathrm{CDCl}_{3}\right) \delta 2.74(\mathrm{~d}, \mathrm{~J}=6.9 \mathrm{~Hz}, 2 \mathrm{H}), 1.68-1.65(\mathrm{~m}, 2 \mathrm{H}), 1.37-1.25(\mathrm{~m}, 16 \mathrm{H}), 0.92-0.89(\mathrm{~m}, 12 \mathrm{H})$.

\section{5,8-Dibromo-2,3-bis(5-(2-ethylhexyl)-3,4-difluorothiophen-2-yl)-6,7-difluoroquinoxaline 7}

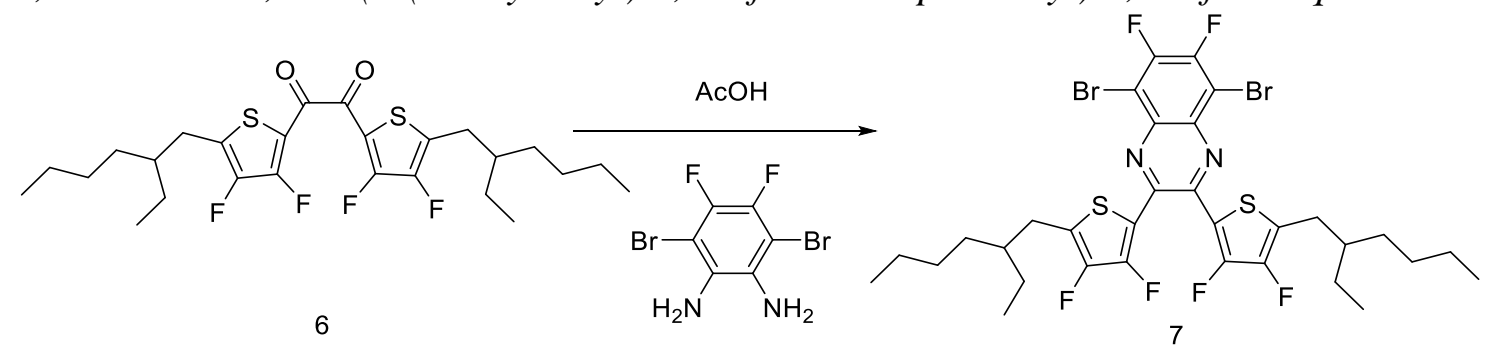

3,6-Dibromo-4,5-difluorobenzene-1,2-diamine $(1.67 \mathrm{~g}, 5.53 \mathrm{mmol})$ was suspended in acetic acid $(100 \mathrm{~mL})$ and compound $6(1.08 \mathrm{~g}, 2.1 \mathrm{mmol})$ dissolved in acetic acid $(60 \mathrm{~mL})$ was added. The suspension was heated at $60{ }^{\circ} \mathrm{C}$ for $1 \mathrm{~h}$ and then the temperature was increased to $120{ }^{\circ} \mathrm{C}$ for $3 \mathrm{~h}$. The solution was stirred overnight at $90^{\circ} \mathrm{C}$. After cooling to room temperature, the mixture was poured into water and extracted with dichloromethane. The organic extraction was washed thoroughly with water and aqueous sodium bicarbonate, dried over magnesium sulfate and evaporated to afford the crude product. The crude product was purified by column chromatography on silica gel using dichloromethane/hexane $=1 / 9(\mathrm{v} / \mathrm{v})$ as eluent. The product 7 was obtained as a yellow viscous liquid (1.47 g, 89.8\% yield). ${ }^{1} \mathrm{H} \mathrm{NMR}\left(400 \mathrm{MHz}, \mathrm{CDCl}_{3}\right) \delta 2.76(\mathrm{~d}, \mathrm{~J}=6.9 \mathrm{~Hz}$, $4 \mathrm{H}), 1.73-1.63(\mathrm{~m}, 2 \mathrm{H}), 1.42-1.26(\mathrm{~m}, 16 \mathrm{H}), 0.96-0.88(\mathrm{~m}, 12 \mathrm{H})$. 


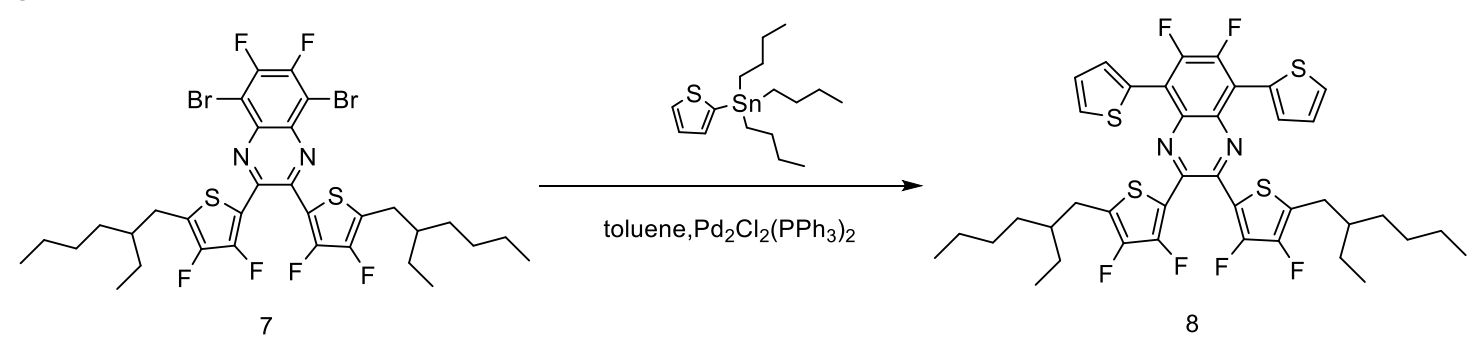

The mixture of compound $7(1.47 \mathrm{~g}, 1.88 \mathrm{mmol})$, tributyl(thiophen-2-yl)- stannane (1.75 g, 4.69 $\mathrm{mmol})$, and $\mathrm{PdCl}_{2}\left(\mathrm{PPh}_{3}\right)_{2}(52.67 \mathrm{mg}, 0.075 \mathrm{mmol})$ in dry toluene $(20 \mathrm{~mL})$ was refluxed for $48 \mathrm{~h}$ under argon. The reaction mixture was allowed to cool to room temperature and the solvent was evaporated under reduced pressure. The crude product was purified by column chromatography on a silica gel using dichloromethane/hexane $(1: 9, \mathrm{v} / \mathrm{v})$ as eluent to afford compound 8 as an orange solid (1.25 g, 84.4 \% yield). ${ }^{1} \mathrm{H}$ NMR (400 MHz, $\left.\mathrm{CDCl}_{3}\right) \delta 8.03(\mathrm{~d}, \mathrm{~J}=3.1 \mathrm{~Hz}, 2 \mathrm{H}), 7.67(\mathrm{~d}, \mathrm{~J}=$ $5.1 \mathrm{~Hz}, 2 \mathrm{H}), 7.27(\mathrm{~d}, \mathrm{~J}=6.4 \mathrm{~Hz}, 2 \mathrm{H}), 2.77(\mathrm{~d}, \mathrm{~J}=6.8 \mathrm{~Hz}, 4 \mathrm{H}), 1.71-1.64(\mathrm{~m}, 2 \mathrm{H}), 1.42-1.34(\mathrm{~m}$, 16H), 0.97-092 (m, 12H).

5,8-Bis(5-bromothiophen-2-yl)-2,3-bis(5-(2-ethylhexyl)-3,4-difluorothiophen-2-yl)-6,7difluoroquinoxaline (M1)

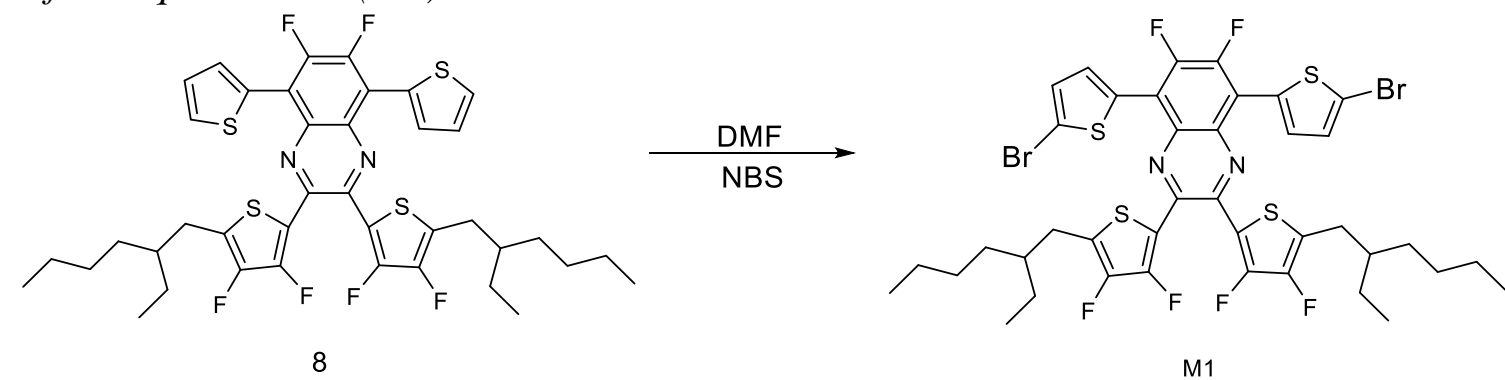

To compound $8(1.25 \mathrm{~g}, 1.58 \mathrm{mmol})$ in dimethyl formamide $(50 \mathrm{~mL})$, the $\mathrm{N}$-bromosuccinimide (NBS) $(0.70 \mathrm{~g}, 3.96 \mathrm{mmol}$ ) was added slowly (40 $\mathrm{min})$ in several portions. The mixture was stirred for $24 \mathrm{~h}$ at room temperature in the dark. The solution was concentrated in vacuum and the residue was purified by column chromatography on a silica gel using dichloromethane/hexane $(1: 10, \mathrm{v} / \mathrm{v})$ as eluent. The product M1 was obtained as a red solid ( $1.21 \mathrm{~g}, 80.5 \%$ yield). ${ }^{1} \mathrm{H}$ NMR (400 MHz, $\left.\mathrm{CDCl}_{3}\right) \delta 7.79(\mathrm{~d}, \mathrm{~J}=4.1 \mathrm{~Hz}, 2 \mathrm{H}), 7.20(\mathrm{~d}, \mathrm{~J}=4.2 \mathrm{~Hz}, 2 \mathrm{H}), 2.81(\mathrm{~d}, \mathrm{~J}=6.7 \mathrm{~Hz}, 4 \mathrm{H}), 1.73-1.70(\mathrm{~m}$, $2 \mathrm{H}), 1.47-1.35(\mathrm{~m}, 16 \mathrm{H}), 0.99-0.90(\mathrm{~m}, 12 \mathrm{H}) .{ }^{13} \mathrm{C} \mathrm{NMR}\left(101 \mathrm{MHz}, \mathrm{CDCl}_{3}\right) \delta 131.99,131.39$, $129.60,125.68,119.13,40.65,32.62,30.19,29.00,25.88,23.08,14.26,11.04,0.15$. 


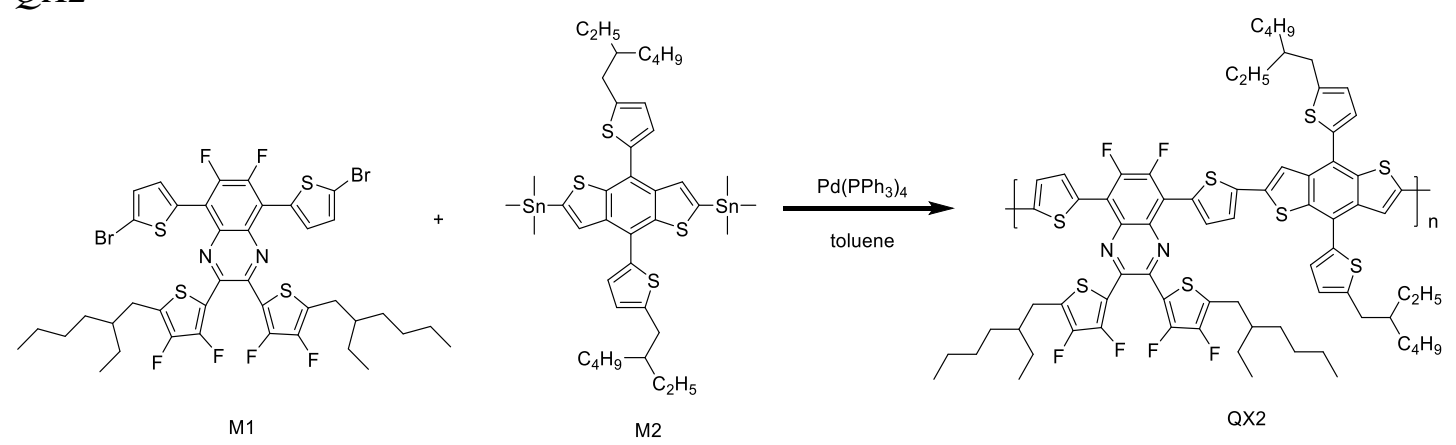

In a $50 \mathrm{~mL}$ two-necked flask, M1 $(0.14 \mathrm{~g}, 0.15 \mathrm{mmol})$ and M2 $(0.14 \mathrm{~g}, 0.15 \mathrm{mmol})$ were dissolved in $10 \mathrm{~mL}$ anhydrous toluene. The reaction system was purged with argon for $10 \mathrm{~min}$ to remove the oxygen. The catalyst $\mathrm{Pd}\left(\mathrm{PPh}_{3}\right)_{4}(13 \mathrm{mg})$ was added quickly into the flask, which was flushed for 5 min with argon again, and the reaction mixture was heated to $110{ }^{\circ} \mathrm{C}$ for $24 \mathrm{~h}$ under vigorous stirring. The reaction mixture was cooled to room temperature, poured into $200 \mathrm{~mL}$ of methanol and the crude polymer precipitated out. After stirring for $30 \mathrm{~min}$, the crude polymer was filtered off and purified by a Soxhlet extraction with methanol, n-hexane, acetone and chloroform successively. The chloroform fraction was collected and evaporated under vacuum to afford the target polymer QX2 as deep green solid (200 mg, 68\% yield). The Mn for QX2 is $52.4 \mathrm{kDa}$, with a PDI of 1.6. ${ }^{1} \mathrm{H}$ NMR $\left(400 \mathrm{MHz}, \mathrm{CDCl}_{3}\right) \delta$ 7.26- 6.95 (br, aromatic protons), 2.90(br, aliphatic protons), 1.55-0.96(br, aliphatic protons).

\section{NMR Spectra}

\section{$\stackrel{m}{i}$}

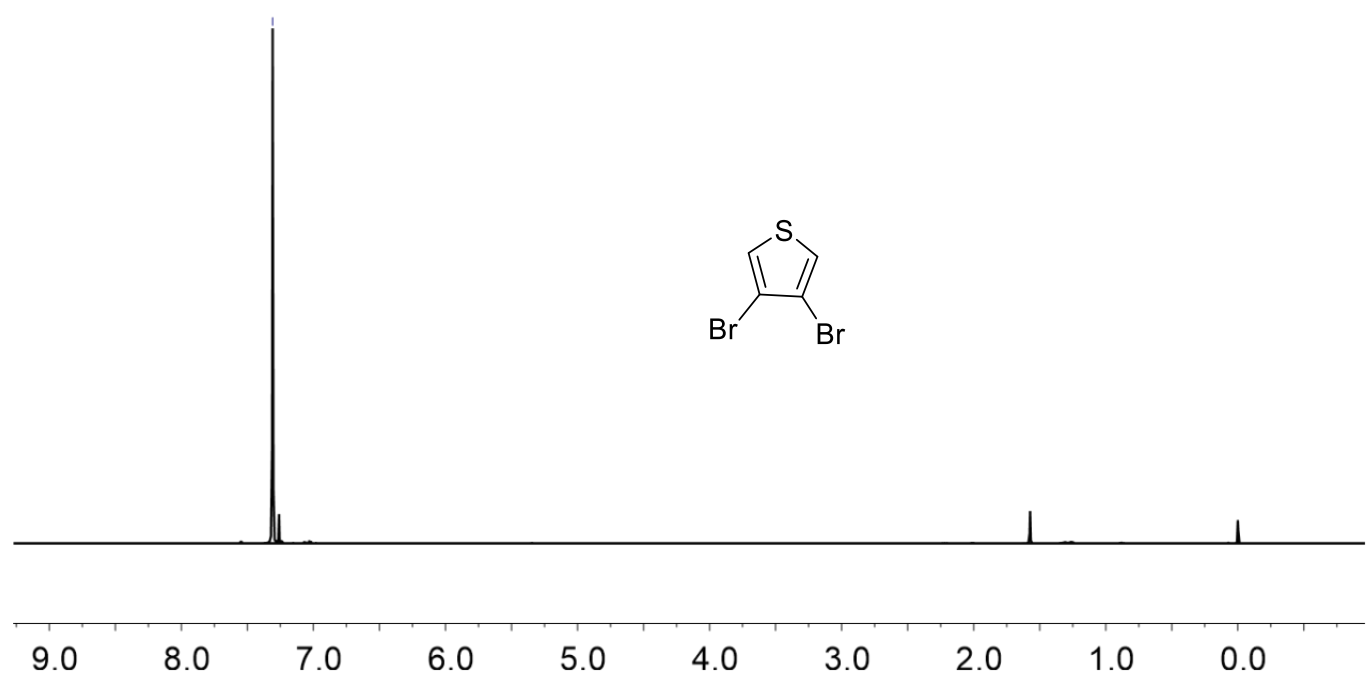

Figure S6. ${ }^{1} \mathrm{H}$ NMR spectrum of Compound 1. 


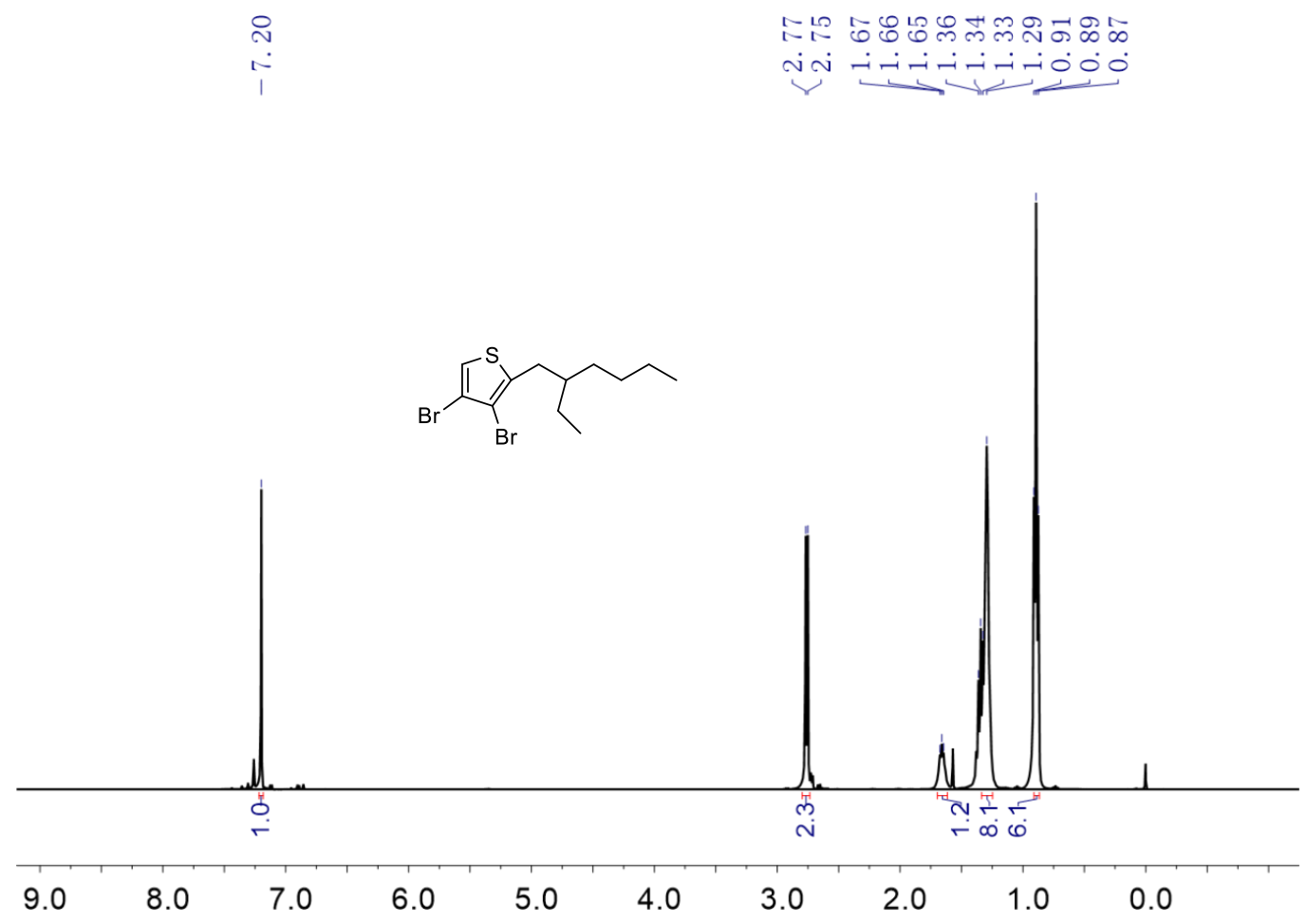

Figure S7 ${ }^{1} \mathrm{H}$ NMR spectrum of Compound 2.
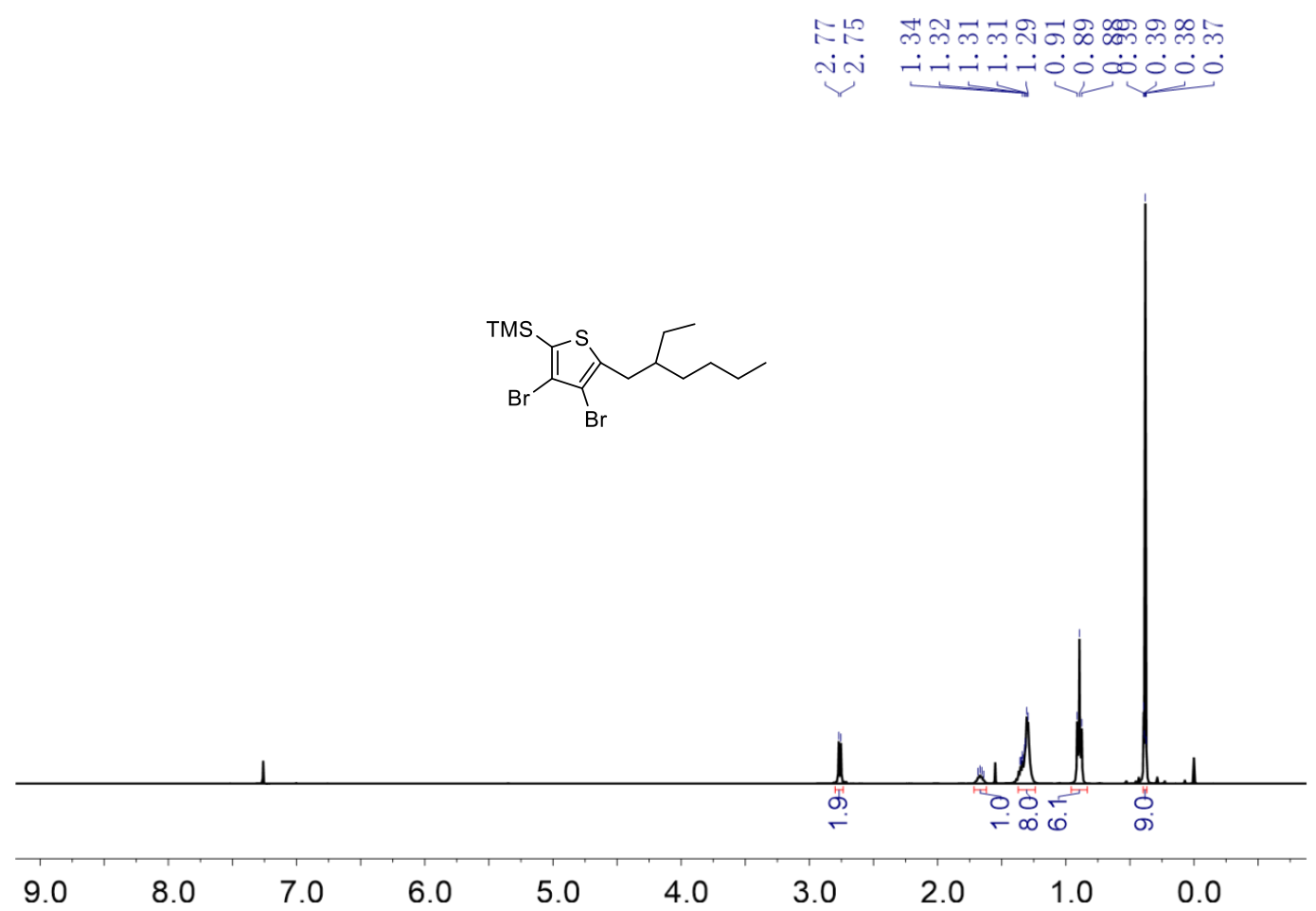

Figure S8. ${ }^{1} \mathrm{H}$ NMR spectrum of Compound 3. 


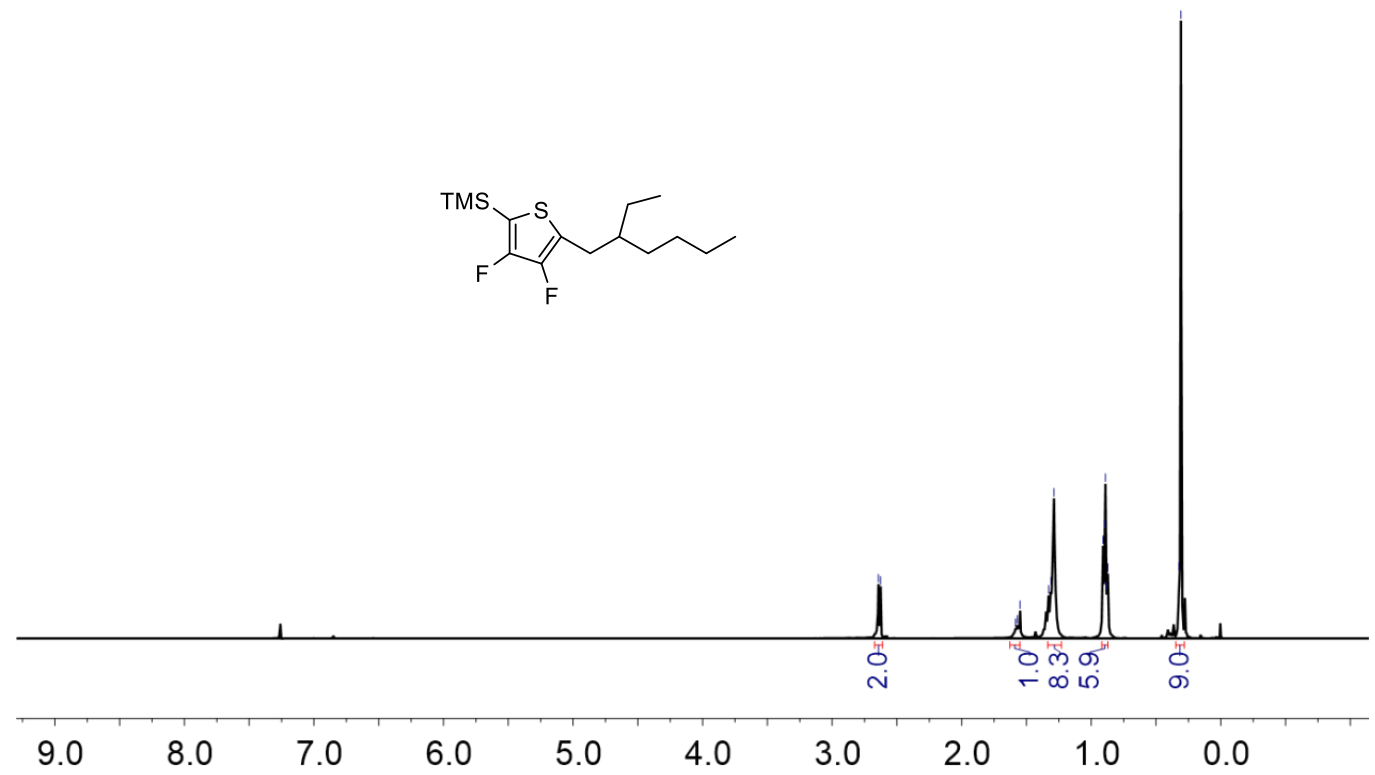

Figure S9. ${ }^{1} \mathrm{H}$ NMR spectrum of Compound 4.

$$
\underbrace{\text { 왁유웡 }}
$$

ชூญ

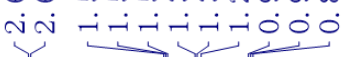

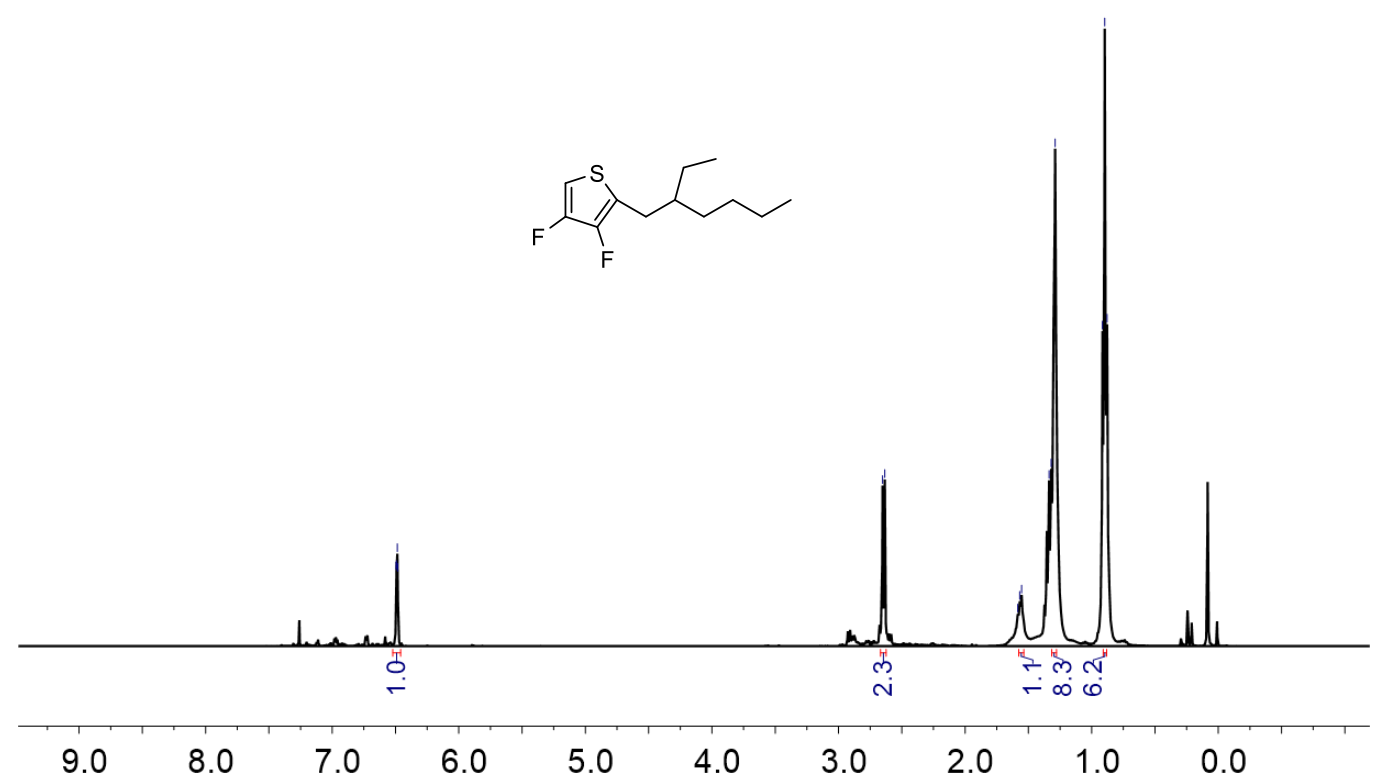

Figure S10. ${ }^{1} \mathrm{H}$ NMR spectrum of Compound 5. 


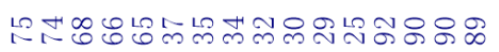

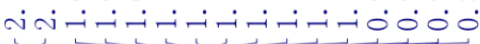

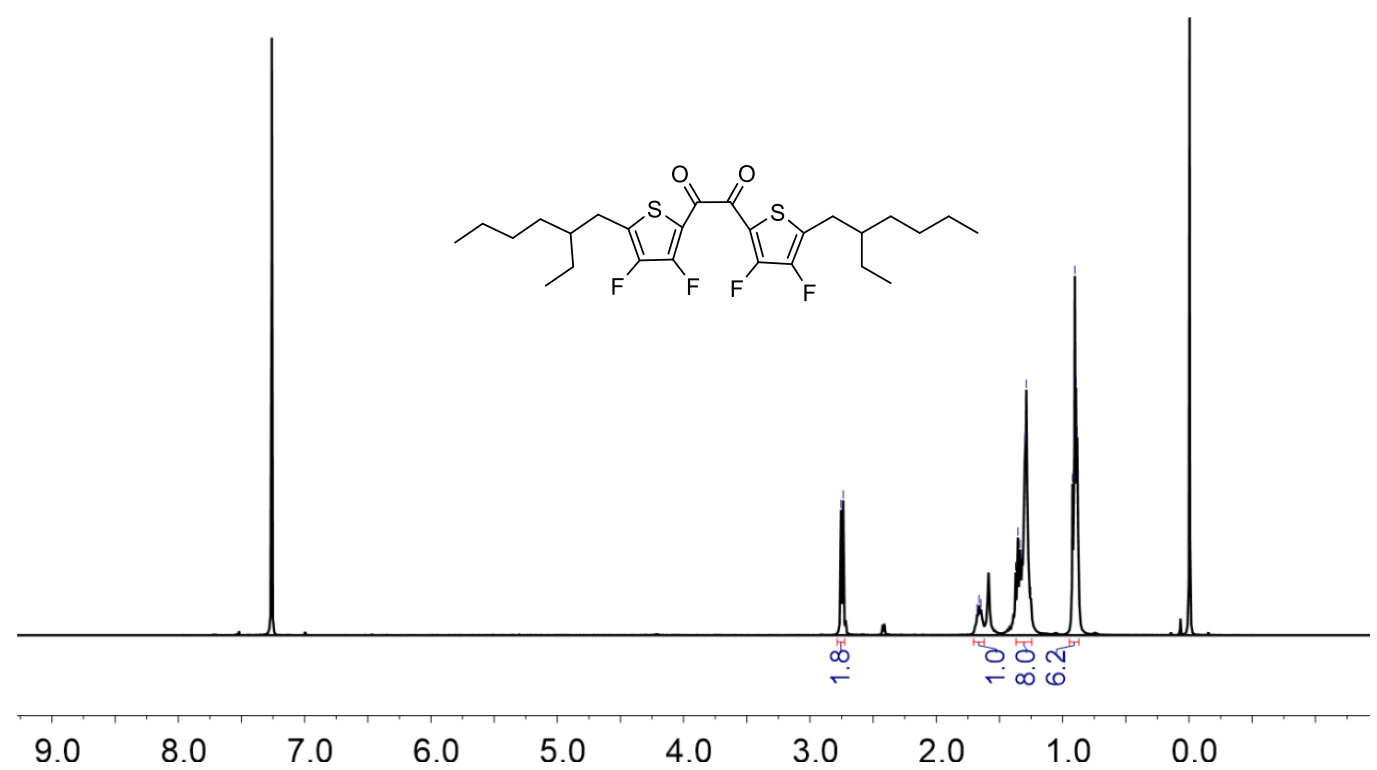

Figure S11. ${ }^{1} \mathrm{H}$ NMR spectrum of Compound 6.

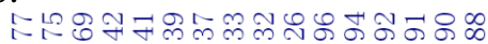

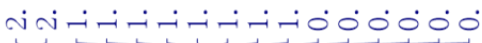

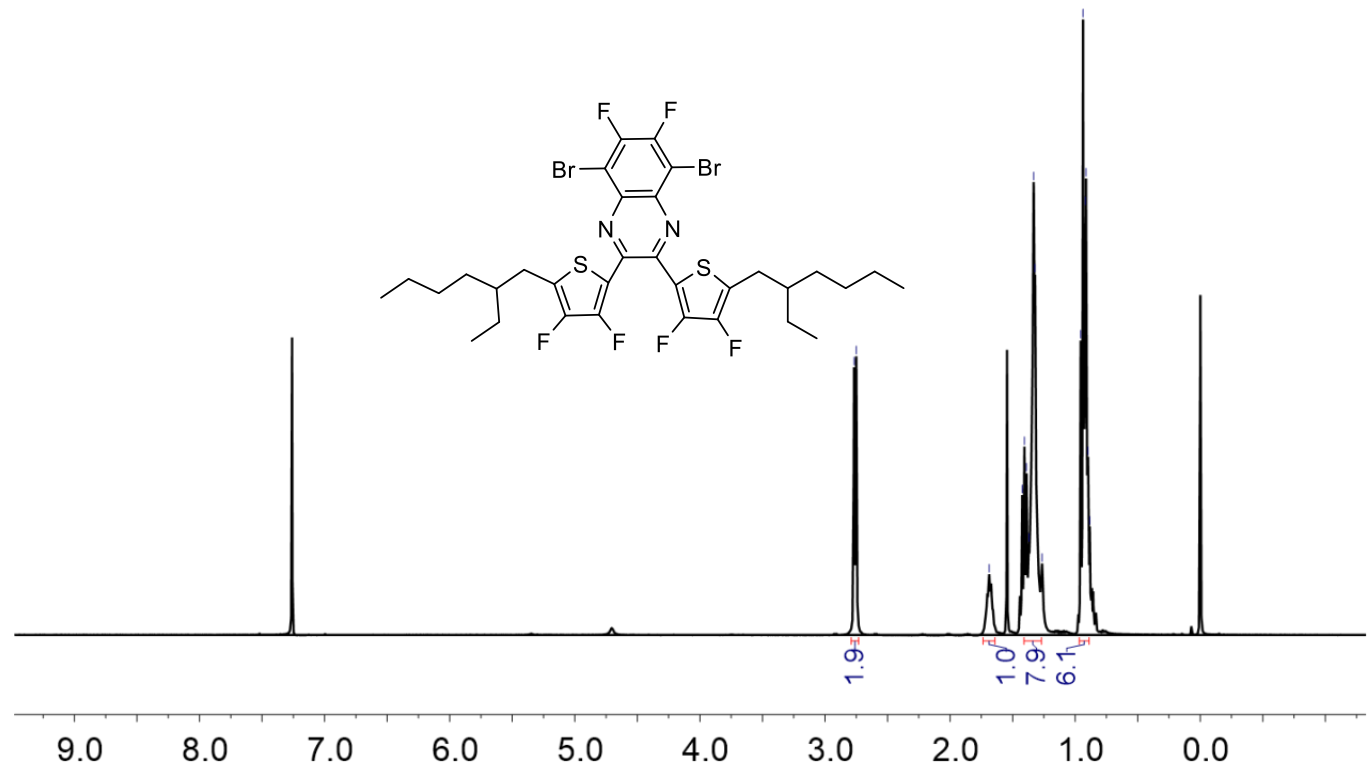

Figure S12. ${ }^{1} \mathrm{H}$ NMR spectrum of Compound 7. 


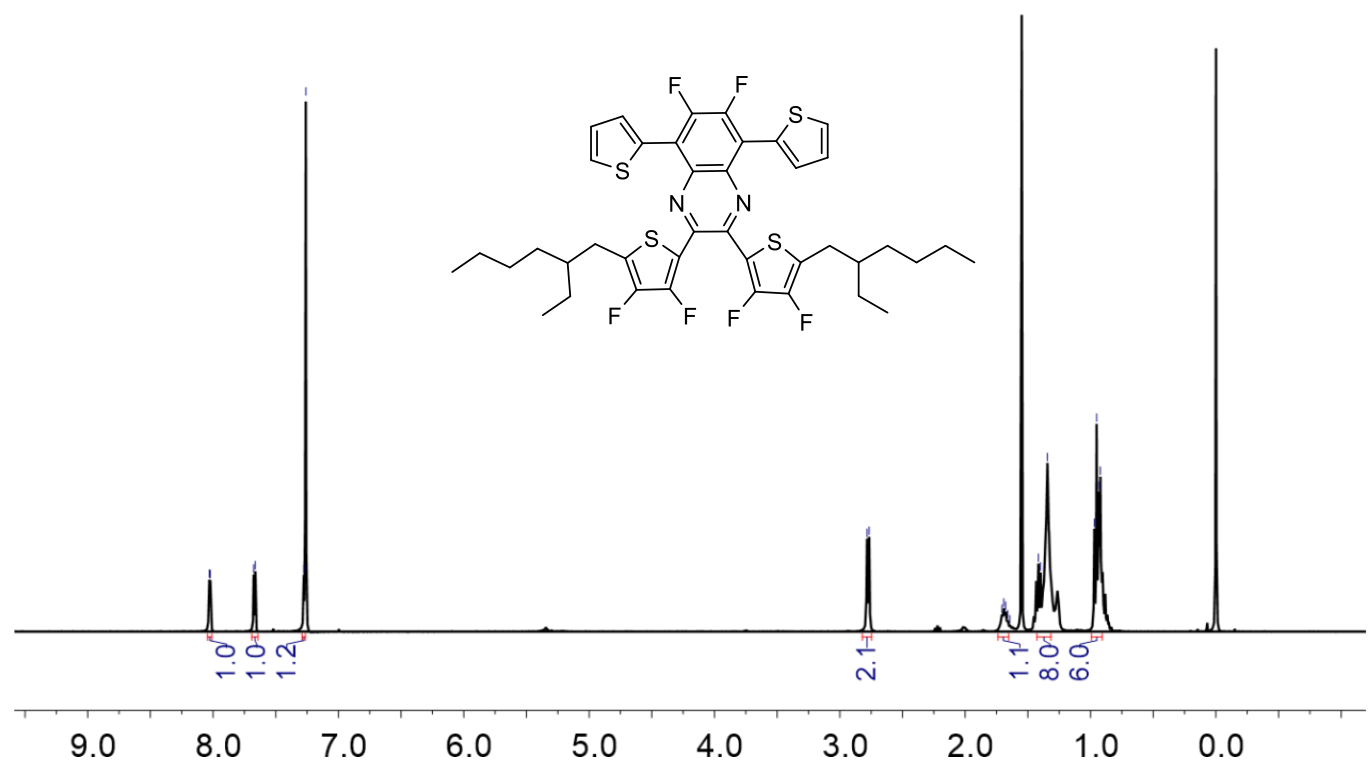

Figure S13. ${ }^{1} \mathrm{H}$ NMR spectrum of Compound 8.

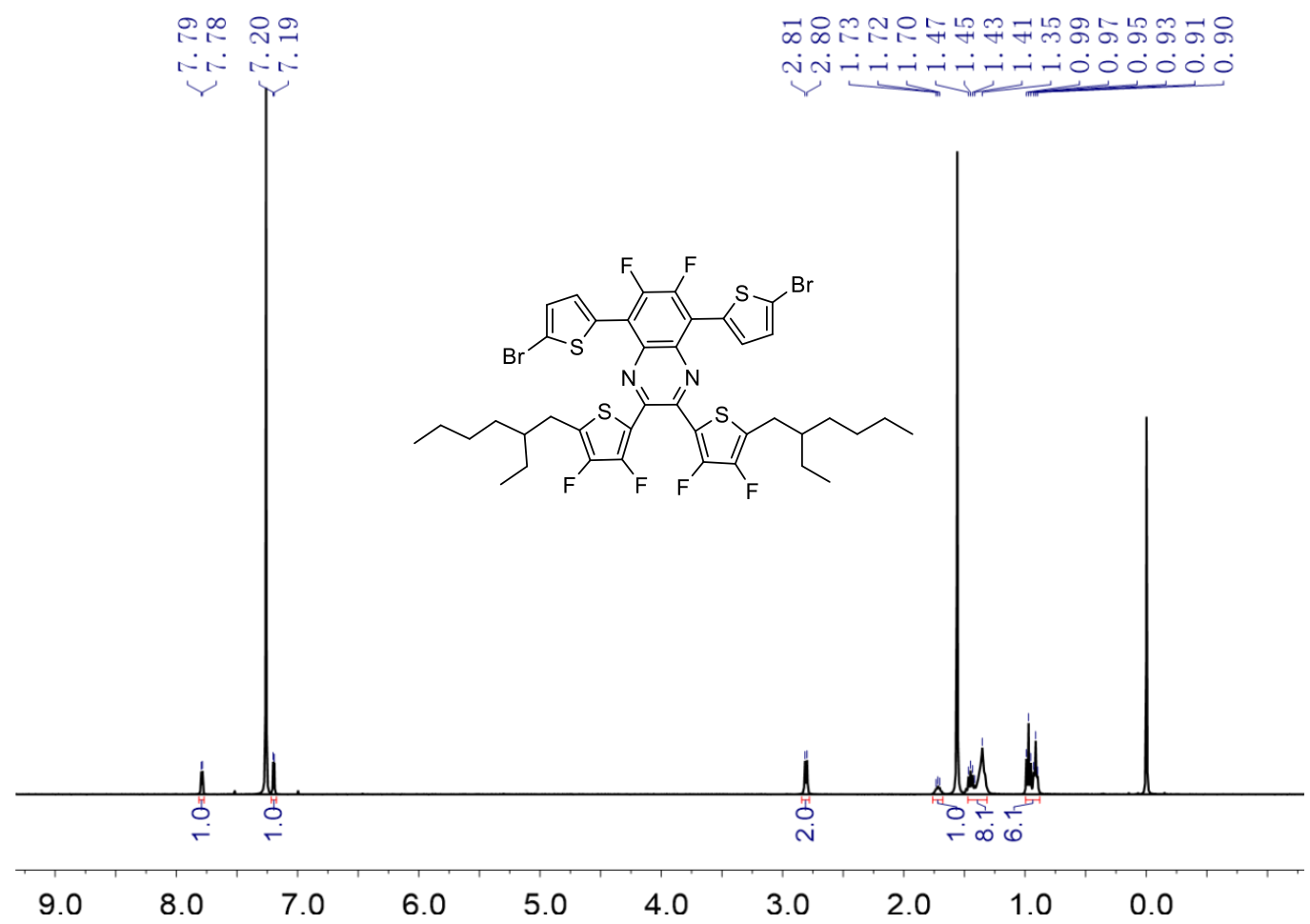

Figure S14. ${ }^{1} \mathrm{H}$ NMR spectrum of M1. 


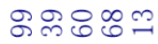

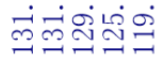

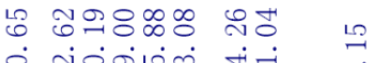

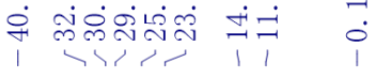

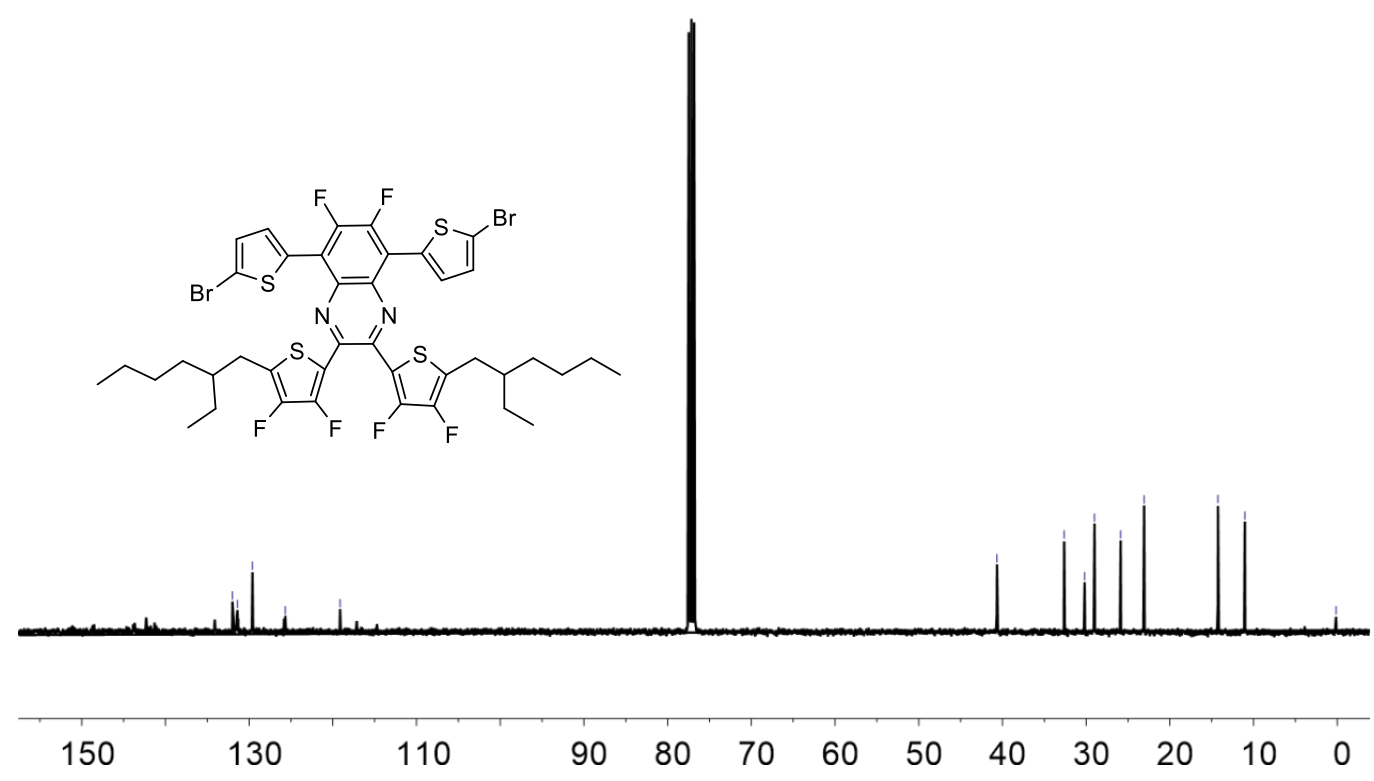

Figure S15. ${ }^{13} \mathrm{C}$ NMR spectrum of M1.
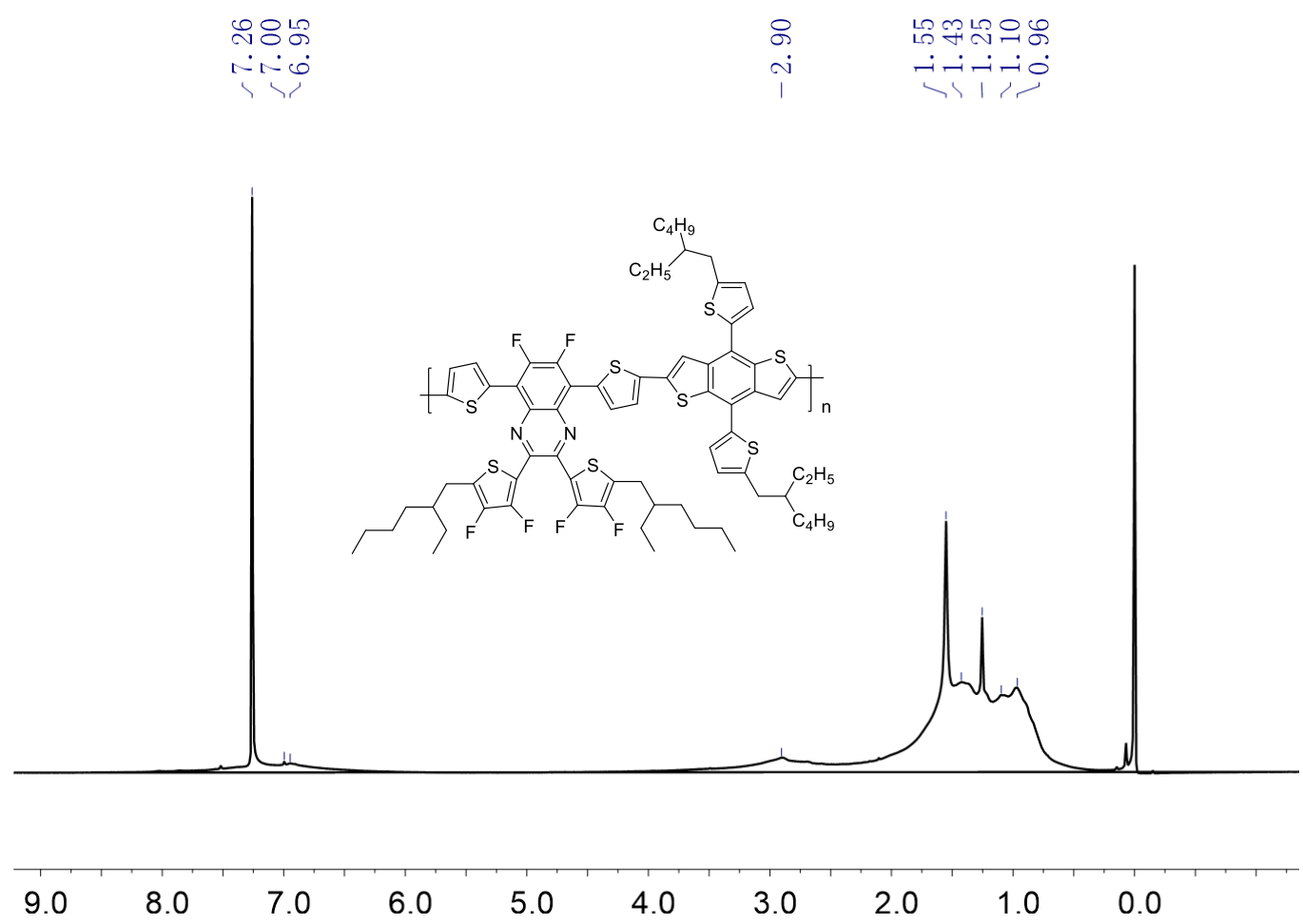

Figure S16. ${ }^{1} \mathrm{H}$ NMR spectrum of QX2. 


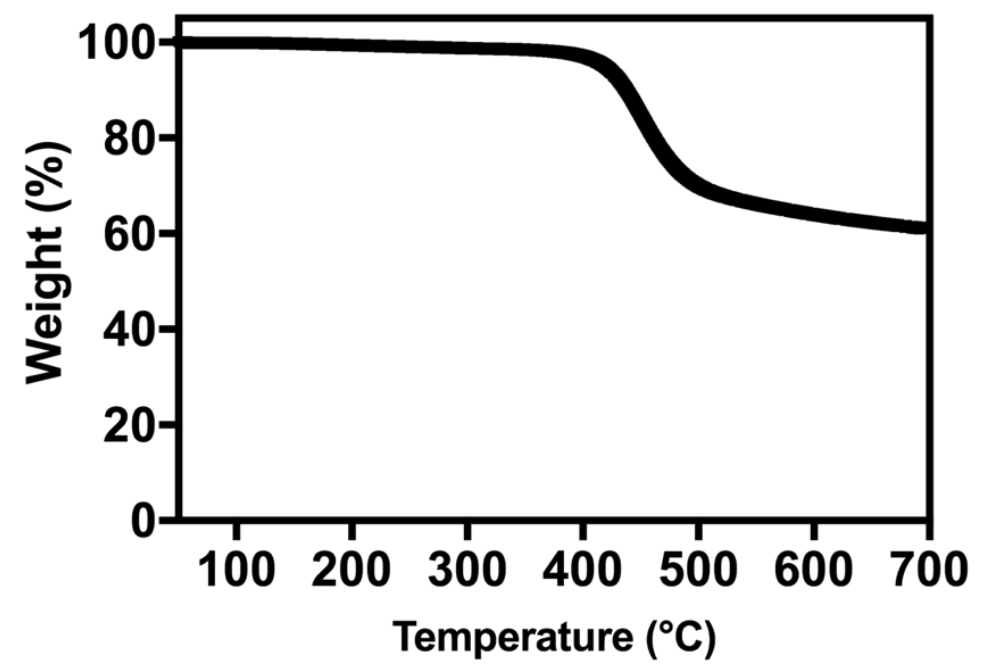

Figure S17. Thermogravimetric analysis of QX2.

\section{$\underline{\text { References }}$}

(1) Wang, T.; Lau, T.-K.; Lu, X.; Yuan, J.; Feng, L.; Jiang, L.; Deng, W.; Peng, H.; Li, Y.; Zou, Y. A Medium Bandgap D-A Copolymer Based on 4-Alkyl-3,5-Difluorophenyl Substituted Quinoxaline Unit for High Performance Solar Cells. Macromolecules 2018, 51, 2838-2846.

(2) Zhou, L.; He, X.; Lau, T.-K.; Qiu, B.; Wang, T.; Lu, X.; Luszczynska, B.; Ulanski, J.; Xu, S.; Chen, G.; et al. Nonhalogenated Solvent-Processed All-Polymer Solar Cells over 7.4\% Efficiency from Quinoxaline-Based Polymers. ACS Appl. Mater. Interfaces 2018, 10, 4131841325.

(3) Xu, S.; Wang, X.; Feng, L.; He, Z.; Peng, H.; Cimrová, V.; Yuan, J.; Zhang, Z.-G.; Li, Y.; Zou, Y. Optimizing the Conjugated Side Chains of Quinoxaline Based Polymers for Nonfullerene Solar Cells with 10.5\% Efficiency. J. Mater. Chem. A 2018, 6, 3074-3083.

(4) Hendsbee, A. D.; Sun, J.-P.; Law, W. K.; Yan, H.; Hill, I. G.; Spasyuk, D. M.; Welch, G. C. Synthesis, Self-Assembly, and Solar Cell Performance of N-Annulated Perylene Diimide Non-Fullerene Acceptors. Chem. Mater. 2016, 28, 7098-7109.

(5) Pommerehne, J.; Vestweber, H.; Guss, W.; Mahrt, R. F.; Bässler, H.; Porsch, M.; Daub, J. Efficient Two Layer Leds on a Polymer Blend Basis. Adv. Mater. 1995, 7, 551-554.

(6) Sun, Y.; Seo, J. H.; Takacs, C. J.; Seifter, J.; Heeger, A. J. Inverted Polymer Solar Cells Integrated with a Low-Temperature-Annealed Sol-Gel-Derived $\mathrm{ZnO}$ Film as an Electron Transport Layer. Adv. Mater. 2011, 23, 1679-1683. 